\title{
Genetics of the mimetic African butterfly Hypolimnas misippus: hindwing polymorphism
}

\author{
Ian J. Gordon* and \\ David A. S. Smith $\dagger \ddagger$
}

\author{
* Department of Zoology, University of Nairobi, \\ P.O. Box 30197, Nairobi, Kenya. \\ $\uparrow$ Department of Biology, Eton College, Windsor, \\ Berkshire SL4 6EW, U.K.
}

\begin{abstract}
The hindwing polymorphism in Hypolimnas misippus is autosomal but sex-limited to the female. It is characterised by three intergrading phenotypes, orange, low white (white in 1-3 intervein spaces) and high white (white in 4-8 spaces). $A$ rare morph has variable melanic scaling, almost invariably in combination with high white. Orange and high white segregate as expected if they are allelic at the $A$ (alcippoides) locus, $A$ giving high white and $a$ orange when homozygous. A postulated $S$ locus also has two alleles, $S$ which suppresses high white in $A-$ genotypes (to low white or orange) and $s$ which is a null allele. The $A$ alleles interact with the $M$ (misippus) locus to affect the forewing: $A A / m m$ (f. alcippoides) has a "misippus" forewing, aa/mm is f. inaria and $A a / m m$ intermediate (f. immima). The dominant $M$ allele is epistatic to $A$ so that all $M$-genotypes have "misippus" forewings. Either a rare dominant gene $B$ (black), or a third, top dominant $A$ allele, $A^{m}$, gives black scaling with high white in the otherwise orange area of the hindwing. The three or four controlling loci all segregate independently.
\end{abstract}

\section{INTRODUCTION}

Hypolimnas misippus (L.) (Nymphalidae), the diadem or danaid eggfly, is something of an evolutionary puzzle. At first glance it looks like a paradigm case of female-limited polymorphic mimicry. The detailed similarities between the colour patterns of four of its female morphs and the four forms of the distasteful African Queen, Danaus chrysippus (L.), (see colour plate in Smith, 1976) inspired Trimen (1887) to declare it "one of the most exact and unmistakeable cases of mimicry known". Poulton (1912) was prepared to abandon the theory of mimicry altogether if the resemblances between the diadem and the queen could be shown to be "merely accidental". Yet the geographical distributions of mimics and models fail to match. This and other anomalies persuaded Bernardi $(1963,1974)$ and Pierre $(1973,1980)$ that the resemblances are indeed largely accidental, a conclusion that would probably make Edward Poulton turn in his grave.

To understand this case of exact mimicry gone wrong, a knowledge of its genetical basis is essential. The dominance order of alleles is particularly relevant as it provides a guide to their mutation

To whom correspondence should be addressed. sequence and spread in evolutionary time (Clarke, Clarke, Gill, Turner and Collins, 1985). Moreover, field evidence exists for strong, though intermittent, selection on female colour patterns at four different sites on five different occasions: Newton, Sierra Leone, 1966 (Unamba, 1968); Legon, Ghana, 1965, 1966 (Edmunds, 1969); Dar-esSalaam, Tanzania, 1974 (Smith, 1976); Cape Coast, Ghana, 1977 (Gordon, 1982, 1987). Although a complex of seasonal and other factors was involved, selection was generally at the expense of forms which were both common and weakly or non-mimetic, suggesting that $H$. misippus is indeed a Batesian mimic. A full genetic model is needed for the correct interpretation of the field results.

In a previous paper we studied the genetics of the misippus-inaria polymorphism for forewing colour and established that a dominant allele $M$ mainly controls the misippus forewing. Recessive $\mathrm{mm}$ genotypes produce a range of colour patterns from the all-orange forewing of pure inaria, through a variety of intermediates (named immima by Bernardi, 1963, a useful name which we wish to resurrect), to what is almost a misippus pattern (Smith and Gordon, 1987). To classify phenotypes we used the method of Edmunds (1969) in which $M$ - butterflies have blw (misippus) forewings and 

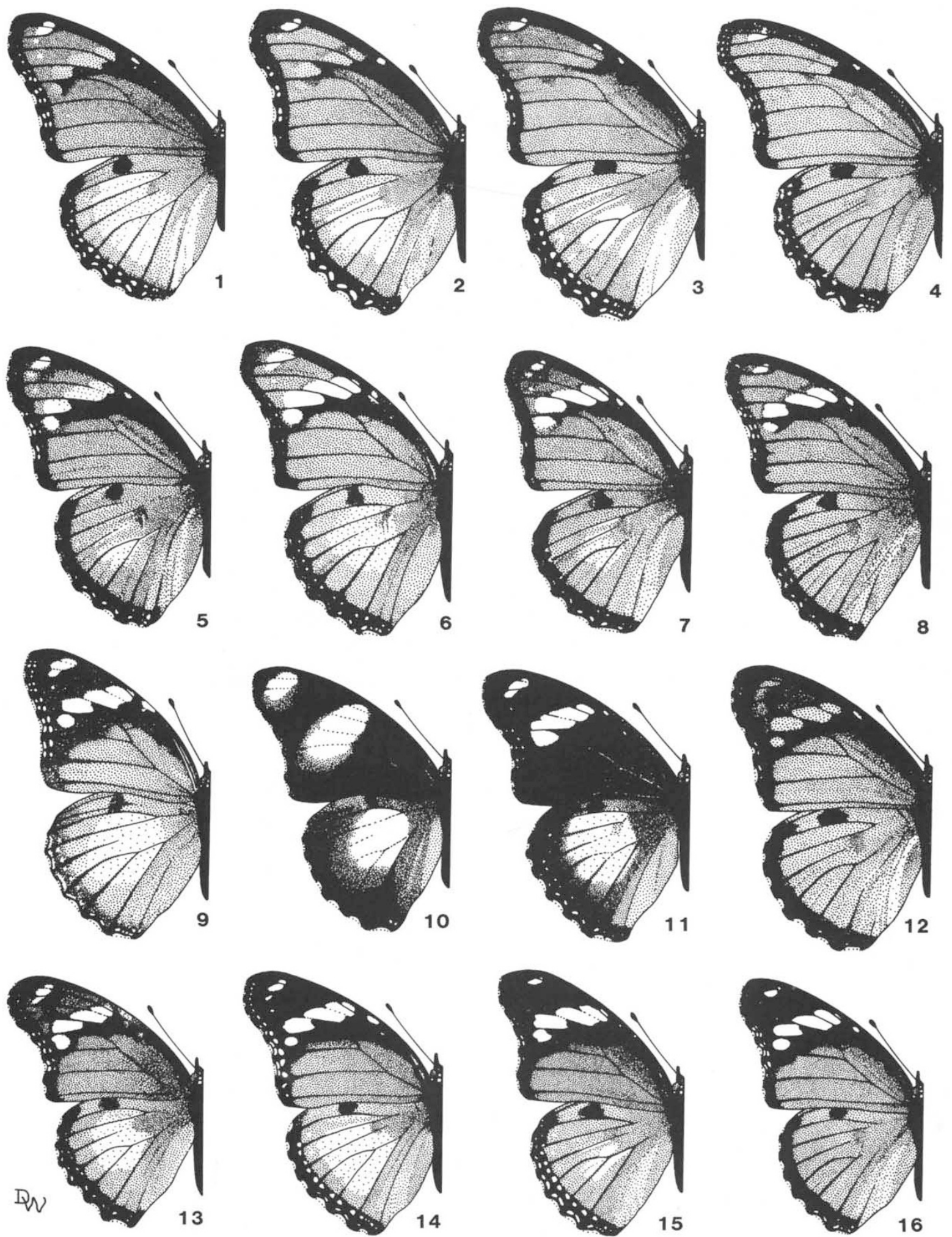
$m m$ may have oo (inaria), op, ow, bro, brp or brw (immima) forewings [see explanations and illustrations in Edmunds (1969), Smith and Gordon (1987), Gordon (1987) and fig. 1].

Here we investigate the genetics of hindwing colour in the female (refer to fig. 1, and table 3 . This may be all orange, as in forms misippus (blw/0) (16), immima (op/0-brw/0) $(8,12)$, and inaria $(o o / 0)(4)$, or may have a white patch of varying size in forms alcippoides (blw/1-8) (9, 14-15) and immima-alcippoides (op-brw/1-8) (1$3,5-7,13)$. The rare form inaria-alcippoides $(\mathrm{oo} / 1-$ 8 ) is not illustrated. We also examine epistasis between the genes for fore- and hindwing colour and analyse the inheritance of a rare and previously unknown male-like or transvestite female form (11).

\section{METHODS}

Here as previously (Smith, 1976; Gordon, 1982, 1987) we use Edmunds' (1969) scoring system for the hindwing which indicates the number of spaces (interveins) affected by the white patch: it ranges from zero $(0)$ (orange) to 10 (almost completely white); scores $>8$ are very rare. A complete phenotype classification combines the hindwing score $(0-10)$ with the seven forewing codes $(b l w$, $o o$ and $o p-b r w)$. One alteration to the established system is the addition of a suffix $M$ for melanic spotting on the hindwing or extension of black scaling on both wings, characters Edmunds did not encounter.

The breeding methods and provenance of stocks have been described elsewhere (Smith and Gordon, 1987). Of 161 broods available from many parts of Africa, only 106 are used here, all reared by I.J.G. in Ghana (Gordon, 1982). The nonGhanaian broods (Smith and Gordon, 1987) were reared by several breeders in widely scattered places and, as scoring methods inevitably differed, the results cannot safely be pooled with those from Ghana.

The male is monomorphic and invariable, so its genotype cannot be inferred by inspection. It follows that 50 per cent of potential genetic information is lost. Though 61 laboratory bred males were used and eight sired more than one brood, unambiguous assignation of genotypes to individual males from the array of their female siblings proved impossible. The obstacles are simultaneous segregations at three or four loci, incomplete penetrance, variable expressivity, epistasis between loci and low viability for some genotypes. These effects combine to produce overlapping female phenotypes in the progenies. Therefore, the segregations obtained are deduced entirely from the phenotypes of the female parent and its progeny. Fortunately, there is extensive replication of almost all brood types, allowing heterogeneity to be tested, and the high mean brood size (females only) of $58 \cdot 1 \pm 39 \cdot 3$, range $5-270,(n=121)$ is useful. Only one brood, which was non-segregating, had less than eight female offspring.

\section{RESULTS}

\section{Quantitative distribution of hindwing white}

One hundred and three progenies were raised in which some or all offspring showed hindwing white. They are divided into two major categories depending on the presence or absence of a gene

Figure 1 A selection of phenotypes of Hypolimnas misippus.
1. $b r p / 7$,
2. $o p / 4$,
3. $\operatorname{brp} / 4$,
4. $o o / 0$,
5. $\operatorname{brp} / 3^{\not \#}$,
6. $o w / 5$,
7. $b r w / 4$
8. $o w / 0$,
9. $b l w / 5 M^{*}$,
10. males $^{\S}$,
11. $b l w 6 / M^{\pi}$,
12. $\operatorname{brp} / 0^{\#}$,
13. $b r w / 5 M^{\dagger}$,
14. $b l w / 5$
15. $b / w / 3$,
16. $b / w / 0$

Stippled areas are brown (dark), orange (intermediate) or pale orange (light), the remaining areas being black or white as shown. The codes $b l$ (black), $b r$ (brown) and $o$ (orange) give the colour of the forewing apex, followed by $o$ (orange), $p$ (pale orange) or $w$ (white) for the sub-apical row of spots. The numbers $(0-8)$ show the number of hindwing spaces with white scales. The suffix $(M)$ indicates melanism, usually on the hindwing only $(9,13)$, but occasionally on both wings (11), giving a male-like or transvestite phenotype. Phenotypes 1-8 and 12-13 are non-misippus (immima or inaria), genotype $m m$ : the M locus genotype of the other specimens (all blw) is unknown.

\footnotetext{
* Specimen from the Nairobi Museum, caught at Katera, Uganda by T. H. E. Jackson in 1939. Melanic scaling is confined to veins in the post-discal area of the hindwing.

$\dagger$ Specimen from Bulawayo Museum caught in 1979 at Bulawayo, Zimbabwe. The brown forewing apex is almost black. Melanic scaling is visible in the basal area of both wings and along veins in the post-discal area of the hindwing.

$\S$ The remaining 15 specimens are all female. Except for the specimens marked* and $\dagger$, all are from Cape Coast, Ghana.

『T Transvestite phenotype, bred by I.J.G. at Cape Coast, Ghana, not recorded in the wild. It is probably homozygous for melanism $(B B)$.

\# Sub-apical row of spots on the forewing is very pale orange.
} 
for melanism, the effect of which is usually confined to the hindwing (fig. 1, Nos. 9 and 13) but occasionally extends to the forewing (No. 11). The desirability of a separate analysis of the "melanic" broods was apparent from the outset as melanism is invariably associated with hindwing white and sometimes other phenotypic effects. Therefore, to avoid possible complications arising from a melanism gene, the 24 broods lacking melanics (Appendix 1) are analysed separately in the first instance.

Fig. 2 shows the different classes of frequency distribution (A1-A7) for hindwing colour detected in "non-melanic" broods. Each histogram illustrates the bulked data for a genetically homogeneous set of broods (see below) which fits one of the several segregations listed in table 1 . Thus the classes are defined by the concordance of genetic and statistical criteria. Visual inspection of the bulked brood data suggests that all seven distributions might differ and $\chi^{2}$ tests for heterogeneity confirm this, all but one comparison giving $P<0 \cdot 001$. Even the most alike pair, Al and A7, differ very significantly $\left(\chi_{[3]}^{2}=14 \cdot 016 ; 0 \cdot 01>\right.$
$P>0.001$, with classes 2-3 and 4-5 amalgamated). None of the distributions is obviously symmetric, all showing, more or less clearly, various degrees of skewness, kurtosis or both. Furthermore, several are polymodal. We should point out that the asymmetry could result, either as an artefact of the scoring method, which creates from a distribution which may be continuous or quasi-continuous, what is essentially a meristic character, over a small range $(0-8)$, or alternatively, from directional dominance at polygenic loci controlling the character. Nevertheless, visual inspection of the data reveals a prevalent discontinuity of phenotypes in the region of 2-3 in the polymodal brood classes which suggests the involvement of a major gene rather than a polygenic system.

The brood classes (fig. 3, B1-7), in which some or all of the female offspring are melanic, show an array of frequency distributions broadly similar to the "non-melanic" broods. There are, however, two prominent differences and a third less obvious. First, there are no "melanic" broods unimodal on $O$ (orange), i.e., equivalent to the Al class in the non-melanics. Second, the discontinuity at $2-3$ is

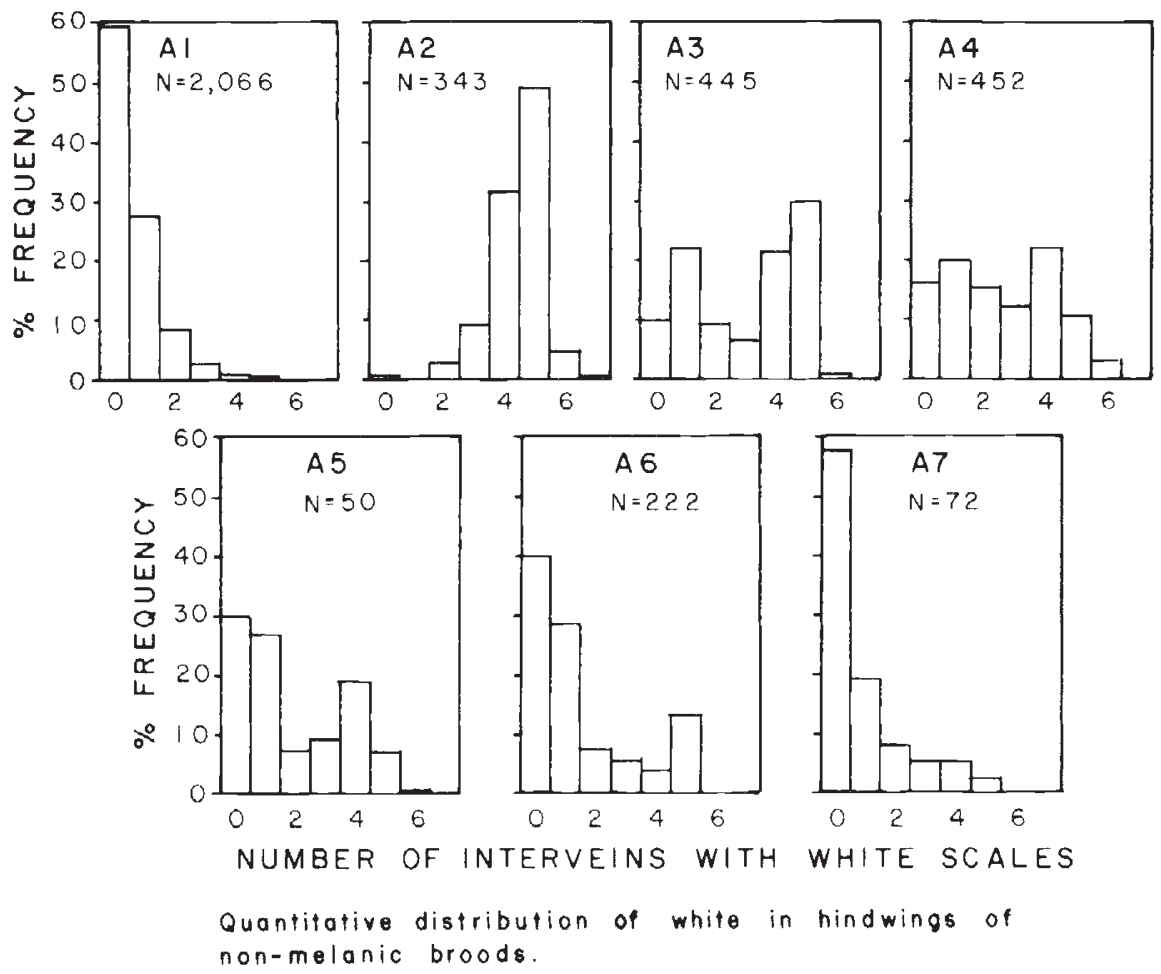

Figure 2 Frequency distribution of white in the hindwings of non-melanic broods. A1 broods have one mode at $O$ (orange-OR); A2 are unimodal for 5 (high white-HW); A3-A6 are polymodal with modes at 1 (low white-LW) and either 4 or 5. A7 may also be polymodal (see text). Proposed segregations for LW/OR: HW are: A1, 1:0; A2, 0:1;A3, 1:1; A4, 5:3; A5, 3:1; $\mathrm{A} 6,13: 3 ; \mathrm{A} 7,7: 1$. 
Table 1 Analysis of all broods segregating for hindwing white

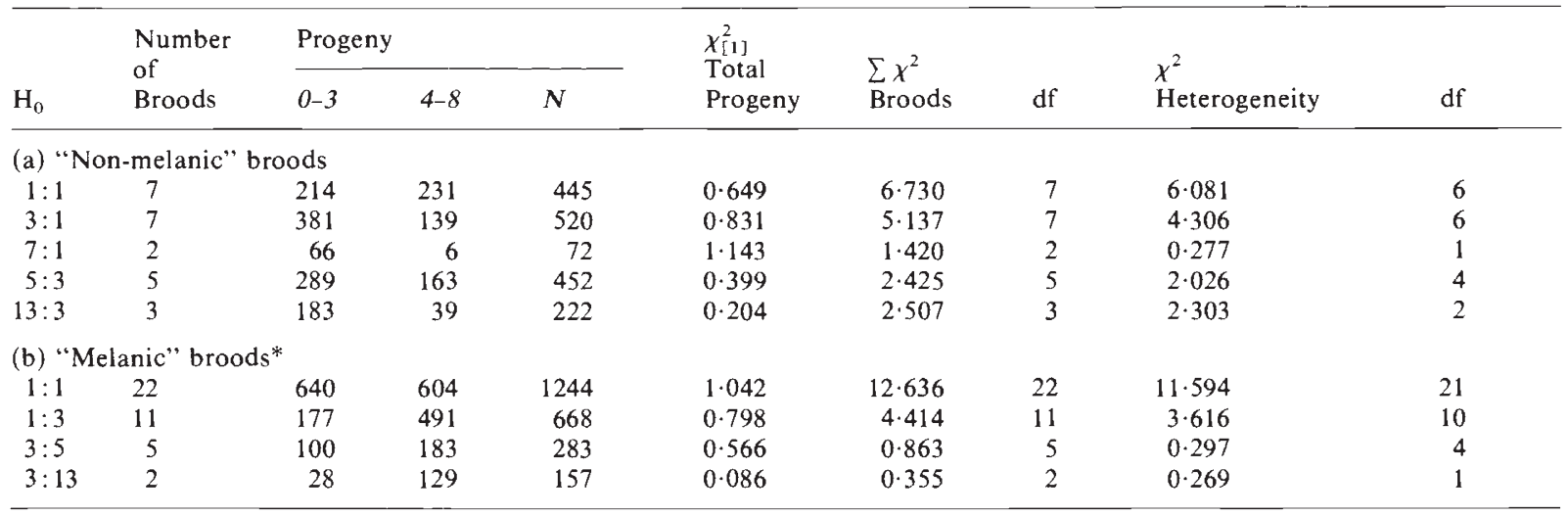

* The heterogeneity tests satisfy both Models I (B locus model) and III ( $A^{m}$ allele model). For other ratios predicted under Model I, see table 5 and Appendix 2.

$\mathrm{df}=$ degrees of freedom. None of the $\chi^{2}$ values is significant for $P \leq 0.05$.

considerably more pronounced than in any of the "non-melanic" classes. Third, the high white mode is more sharply and consistently defined at 5 and the two comparable distributions $\mathrm{A} 2$ and $\mathrm{B} 1$ (classes $0-4,5$ and $6-8)$ consequently differ $\left(\chi_{[2]}^{2}=\right.$ $14.179 ; P<0 \cdot 001)$. The mean score for white, again comparing $\mathrm{A} 2(\bar{x}=4 \cdot 50)$ and $\mathrm{B} 1(\bar{x}=4 \cdot 75)$, is slightly but very significantly higher in the melanics $\left(d=3 \cdot 486\right.$, tested as a $t_{[260]}$ with unequal sample variances, $0 \cdot 002>P>0 \cdot 001$, Bailey, 1959).

At this stage of the analysis there are at least three types of competing interpretations of the data. (1) The presence or absence of white is controlled by a single gene and the different amounts of white depend on the genetic background. In this case white is allelic to orange. (2) The amount of white is controlled by multiple alleles for, say, high white, low white and orange, possibly with overlapping effects or intermediate heterozygotes. (3) Colour is controlled by a small number of major genes with some sort of interaction between them. Each model generates a different set of expectations in terms of frequency distributions.

\section{Segregations for orange and white in "non-melanic" broods}

Initially we tried to detect segregations by dividing progenies into orange and white classes, neglecting quantity of white. This method yields unclassifiable results ranging from all orange to all white with a continuous array of intermediate combinations. Moreover, all orange, all white, ostensibly $3: 1$ (orange: white) and $1: 3$ broods, and a variety of other ratios, could apparently be obtained from female parents of either colour. From these early efforts it was clear that a simple one locus model, even allowing for multiple alleles, could not accomodate the data. Thus, hypotheses (1) and (2) above were rejected.

A more promising approach followed the identification of two modal classes $0-3$ and $4-8$, which are consistently characterised in polymodal broods by peaks at $0-1$ (i) and $4-5$ (ii), the two modes being almost invariably separated by a discontinuity in the $2-3$ region (iii). With the exception of A7 (see below), if characters (i) or (ii) occur alone (A1-A2), the brood is considered to be nonsegregating (raw data omitted). On the other hand, for broods displaying characters (i), (ii) and (iii), the ratio $0-3: 4-8$ is tested by $\chi^{2}$ for best fit to a variety of possible one- and two- locus Mendelian models. As expected, many broods, especially the smaller ones, fit more than one hypothesis (Appendix 1) though encouragingly few give an improved fit if the distribution of phenotypes is partitioned differently. However, it has not escaped our attention that, with 94 segregations tested in this paper, the risk of Type I Error is unacceptably high if the conventional five per cent significance level is used. Therefore, for individual broods we accept a hypothesis as definitive only if all other possibilities are rejected at the one per cent level. Mutatis mutandis, a fit is not decisively rejected unless $\chi^{2}$ gives $P<0 \cdot 01$.

The raw data are summarised in table 1(a). Fourteen of the 24 broods fit either one locus backcross or F2 expectations, but the remaining 10 give better fits to other models. Five broods best fit 5:3 and G019 definitively fits only this 


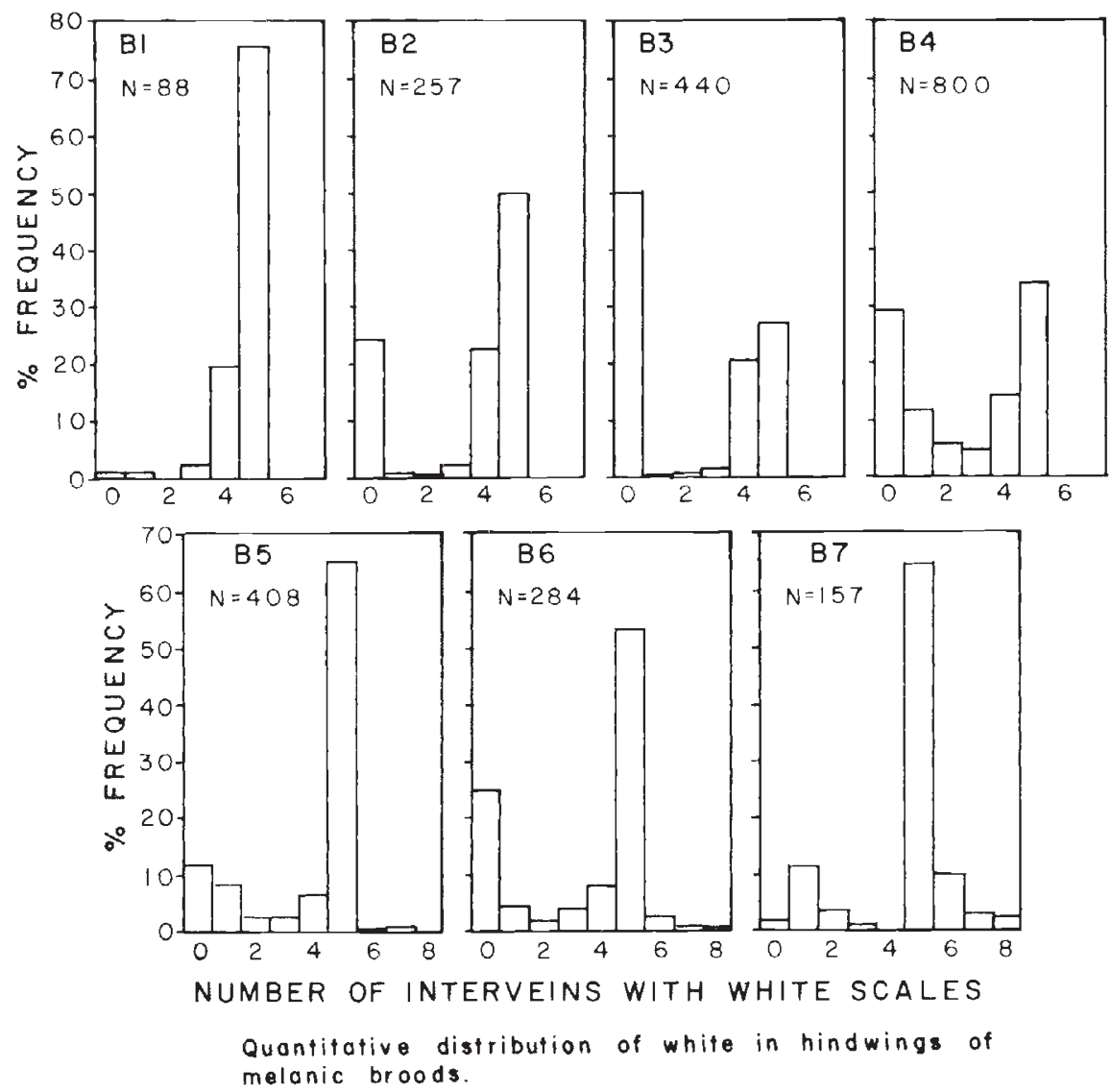

Figure 3 Frequency distribution of white in the hindwings of melanic broods neglecting $O$ (OR). B1-B3 broods are unimodal for 5 (HW) and B4-B7 are polymodal with modes at 1 (LW) and $5(\mathrm{HW})$. Proposed segregations for LW/OR: HW are: B1, 0: 1; $\mathrm{B} 2,1: 3 ; \mathrm{B} 3,1: 1 ; \mathrm{B} 4,1: 1 ; \mathrm{B} 5,1: 3 ; \mathrm{B} 6,3: 5 ; \mathrm{B} 7,3: 13$.

hypothesis. Inclusion of the $5: 3$ broods in either the $1: 1$ or $3: 1$ series destroys their homogeneity. A further five broods best fit either $13: 3$ or $7: 1$ although several also fit $3: 1$ less satisfactorily. However, all attempts to classify the 24 broods into one locus F2 and backcross series produce significant $\chi^{2}$ values for total progeny, summation, heterogeneity or combinations of two or three of these. Furthermore, both orange and white can behave as either dominant or recessive characters as all white offspring were obtained from an orange mother (G057) and all orange from a white one (G032, G034, G039) (non-segregating broods not included in Appendix 1).

A two locus hypothesis involving epistasis (table 2) can explain the "non-melanic" results. Its main features are probably as follows. (1) An A (alcippoides) locus has two alleles. The dominant $A$ allele gives a white patch with a modal value around 5 (high white-HW) and the recessive $a$ gives orange (OR). (2) An independent $\mathrm{S}$ (white suppressor or extension of orange) gene has two alleles, $S$ which partly or entirely suppresses white, so that $A-/ S$ - butterflies may either be orange or have a small white area which falls mostly in the range 1-3 (low white-LW), with a modal value of 1 , and $s$, which is probably a null allele. (3) Both $a a /$ - - and $A-/ S$ - genotypes may be orange, the former invariably so. The proportion of OR and LW individuals in the latter genotype varies between broods; consequently, the ratio $\mathrm{OR}: \mathrm{LW} / \mathrm{HW}$ is unpredictable and useless for most genetic analysis. (4) Independent segregation at two loci with epistasis (fig. 2, table 2) produces 13:3 (two locus F2, A6), 7:1 (one locus backcross, one locus F2, A7) and $5: 3$ (reciprocal F2 and backcross, A4) results in addition to $1: 1$ (A3) and 3:1 (A5) segregations. 
Table 2 Possible segregations (LW/OR: HW or $0-3: 4-8$ ) in "non-melanic" broods under a two-locus model with $S$ epistasic to $A$ (the A-S Model)

\begin{tabular}{llcll}
\hline \multicolumn{4}{l}{ Crosses at S locus } & \\
\cline { 2 - 3 } Crosses at A locus & $S S \times--$ & $S s \times S s$ & $S s \times s s$ & $s s \times s s$ \\
\hline$A A \times A A, A a$ or $a a$ & $1: 0$ & $3: 1$ & $1: 1$ & $0: 1$ \\
$A a \times A a$ & $1: 0$ & $13: 3$ & $5: 3$ & $1: 3 \dagger$ \\
$A a \times a a$ & $1: 0$ & $7: 1$ & $3: 1$ & $1: 1 \dagger$ \\
$a a \times a a$ & $1: 0$ & $1: 0$ & $1: 0$ & $1: 0$ \\
\hline
\end{tabular}

$\mathrm{LW}=$ low white, $\mathrm{OR}=$ orange, $\mathrm{HW}=$ high white.

† Segregations not recorded.

This hypothesis satisfactorily accomodates all 24 segregating "non-melanic" broods and a further 40 non-segregating broods ( $\mathrm{A} 1$ and $\mathrm{A} 2$ ). Two of the segregations it predicts were not observed, namely $1: 1$ for OR (i.e., lacking $\mathrm{LW}$ ) and $\mathrm{HW}$ and $1: 3$. G067 gives an excellent fit to $1: 3$ but does not fit the model as it has modes at 2 (LW) and 4. A similar restriction operates in the case of G083 which fits $7: 1$ better than $13: 3$ but has too few OR offspring. The broods best fitting 7:1 deserve special comment. The frequency distribution (A7) differs from prediction as it should have a major mode at 0 and a minor one at 4-5. However, the two broods in this class are both in fact bimodal, one with a minor mode at 4 and the other at 5 : when the two minor modes are merged they fail to show in the bulked data.

An alternative two-locus hypothesis involving the $\mathrm{A}$ and $\mathrm{M}$ loci, both of which play a part in the control of forewing phenotype, can be envisaged for the hindwing. Given that $A A / \mathrm{mm}$ is $b / w / 4-8$ (alcippoides), $A a / \mathrm{mm}$ has an intermediate immima forewing with 4-8 hindwing and $\mathrm{aa} / \mathrm{mm}$ is inaria with orange fore- and hindwings, reflecting the total dominance of $A$ over $a$ for hindwing high white and its shared dominance for forewing, the $\mathrm{M}$ locus genotype may modify the hindwing phenotype in some way, as it is known to do for the forewing (Smith and Gordon, 1987). All $M-$ genotypes have misippus forewings: thus the $M$ allele converts immima and inaria to misippus. If the $\mathrm{M}$ gene also modifies the hindwing expression of the A locus, a range of intermediates could be produced by the various $\mathrm{A}$ and $\mathrm{M}$ combinations. However, we are unable to find any A-M model which satisfies both the known interactions controlling the forewing phenotype and the results reported here for the hindwing, particularly for broods which segregate for both sets of characters. There is an insuperable obstacle to this model: to satisfy the condition that both orange and high white in the hindwing may be dominant characters, and $A$ is clearly dominant for white (this paper), $M$ must be dominant for orange. As the immima ( $A a)$ forewing is always converted by $M$ to misippus, white hindwinged immima would not be possible, whereas in fact immima most commonly has a LW hindwing. We therefore reject an A-M hypothesis in favour of the A-S hypothesis. The matching phenotypes and genotypes under the A-S hypothesis are shown in table 3 .

The segregations for $0-3: 4-8$ are almost discrete but there is considerable overlap, probably due to the variable phenotypes of $A-/ S-$ (LW) and $A-/ s s(\mathrm{HW})$ genotypes. Judging from the two unimodal brood types A1 and A2 (fig. 2), we expect overlap in the range 2-4. The proportion of $A-/ S-$ genotypes with a score $>3$ cannot be estimated with any precision from $A 1$ but is at least 1.0 per cent and is expected to be rather more as variable proportions of the $1228 \mathrm{OR}$ offspring are $a \mathrm{a} /--$. The proportion of whites scoring $<4$ in $A-/$ ss genotypes is more reliably estimated as 12.7 per cent in A2 broods. It follows that some misidentification of genotypes is inevitable and thus probably led to some $0-3: 4-8$ segregation ratios being incorrectly classified. One further brood deserves comment in this context: G022, classified as $7: 1$, came from an op 5 female, whereas under the A-S model (table 2) the mother should have been LW. It could be a rare case of a HW $A a / S s$ female; alternatively, the two $\mathrm{HW}$ progeny could be $A a / S$ s (or contaminants) in a 1:0 brood.

\section{Segregation for orange and white in "melanic" broods}

The 42 "melanic" broods (fig. 3) can be classified along similar lines with Mendelian segregations for $0-3: 4-8$. LW $(0-3)$ are missing from 17 of them, two of which, both from $b l w / 5 M$ mothers, are $0: 1$ for OR: HW (B1), while the other 15 (Appendix 
Table 3 The phenotypes, genotypes under the A-M-S Model and morph nomenclature of the female forms of H. misippus

\begin{tabular}{|c|c|c|c|c|}
\hline \multirow{2}{*}{$\begin{array}{l}\text { Genotypes at } \\
\mathrm{S} \\
\text { locus }\end{array}$} & \multirow{2}{*}{$\begin{array}{l}\mathrm{M} \\
\text { locus }\end{array}$} & \multicolumn{2}{|l|}{ A locus } & \multirow[b]{2}{*}{$a a$} \\
\hline & & $A A$ & $A a$ & \\
\hline \multirow[t]{2}{*}{$S-$} & $M-$ & $\begin{array}{l}\text { blw/0-3 } \\
\text { weak alcippoides } \\
(1-3)(\mathrm{LW}) \text { or } \\
\text { misippus }(0)(\mathrm{OR})\end{array}$ & $\begin{array}{l}\text { blw/0-3 } \\
\text { weak alcippoides } \\
(1-3)(\mathrm{LW}) \text { or } \\
\text { misippus }(0)(\mathrm{OR})\end{array}$ & $\begin{array}{l}\text { blw/0 } \\
\text { misippus (0) (OR) }\end{array}$ \\
\hline & $m m$ & $\begin{array}{l}\text { blw/0-3 } \\
\text { weak alcippoides } \\
(1-3)(\mathrm{LW}) \text { or } \\
\text { misippus }(0)(\mathrm{OR})\end{array}$ & $\begin{array}{l}\text { bro, brp, or op } / 0-3 \\
\text { weak immima- } \\
\text { alcippoides }(1-3) \\
\text { (LW) or immima }(0) \\
\text { (OR) }\end{array}$ & $\begin{array}{l}o o / 0 \\
\text { inaria }(0)(\mathrm{OR})\end{array}$ \\
\hline \multirow[t]{2}{*}{ ss } & $M-$ & $\begin{array}{l}\text { blw/4-8 } \\
\text { alcippoides ( } \mathrm{HW})\end{array}$ & $\begin{array}{l}\text { blw/4-8 } \\
\text { alcippoides (HW) }\end{array}$ & $\begin{array}{l}\text { blw/0 } \\
\text { misippus (O) (OR) }\end{array}$ \\
\hline & $m m$ & $\begin{array}{l}\text { b/w/4-8 } \\
\text { alcippoides (HW) }\end{array}$ & $\begin{array}{l}\text { ow, brp or brw } / 4-8 \\
\text { immima-alcippoides } \\
(\mathrm{HW})\end{array}$ & $\begin{array}{l}o o / 0 \\
\text { inaria }(0)(\mathrm{OR})\end{array}$ \\
\hline
\end{tabular}

See text for explanation of phenotype codes. The hindwing colour class abbreviations used throughout the text are $\mathrm{HW}=$ high white $(4-8), \mathrm{LW}=$ low white $(1-3), \mathrm{OR}=$ orange $(0)$.

2) are divided into two formally homogeneous series of broods which segregate $1: 3$ (B2) and $1: 1$ (B3). They may be interpreted respectively as one locus F2 and backcross segregations for a dominant $A$ allele and the recessive $a$ : as melanism in these broods is strongly associated with $\mathrm{HW}$, it is possible that different $\mathrm{A}$ alleles control $\mathrm{HW}$ in "melanic" and "non-melanic" broods. Alternatively, an independent locus might control melanic high white (MHW). Only $2 \cdot 3$ per cent $(n=301)$ of butterflies scoring 4 have traces of melanism. As melanism is otherwise associated only with $\mathrm{HW}$, occasional low white melanics (MLW) are probably dominant genotypes with low expressivity for both characters.

The remaining 25 "melanic" broods (B4-B7, listed in Appendix 2 and analysed in table 1(b) all have some non-melanic (NM), LW offspring which are presumably $A-/ S-$. They can be classified into $1: 1,1: 3,3: 5,3: 13$ and $1: 7$ (not recorded) segregations by a simple extension of the hypothesis for "non-melanic" broods. Comparing these segregations with their "non-melanic" counterparts, it is clear that MHW is not suppressed by $S$, a difference further supporting the suggestion that $\mathrm{HW}$, when associated with melanism, is controlled by a different allele or gene which is expressed irrespective of the genotype at the $\mathrm{S}$ locus. A mechanism of this sort would explain why low white melanics are rare (six observed) and orange melanics unrecorded.

\section{The inheritance of melanism}

Early in the Ghana breeding programme a female alcippoides (blw/5) captured in the field gave progeny $(\mathrm{G} 020)$ of which a portion showed traces of melanism in the hindwing. Subsequently a melanic (blw/5M) female, taken from the field, produced brood G049 in which approximately half displayed some melanism. All other melanic broods were descended from this female.

Melanism is usually confined to the hindwing. Only when it is heavily developed (fig. 1, specimen 11) does it spread to the forewing; this was seen in only 4.7 per cent of 910 melanic butterflies subjected to scrutiny. In many cases melanism was associated with the blue iridescence that surrounds the white patches in the male, giving a decidedly male-like or transvestite (Clarke et al., 1985) appearance. Iridescence was also apparent in the rare melanic forewings. None of the melanic females examined was without some white on the hindwings and 98.8 per cent scored $>3$.

The data suggest that melanism could be controlled by several genetic mechanisms with features broadly as follows:

Model I. A postulated B (black) locus, independent of the A locus, controls $\mathrm{HW}$, melanism and iridescence. It also converts the immima/inaria forewing to misippus or near-misippus (brw). The $B$ allele is therefore dominant and epistatic to the $\mathrm{A}, \mathrm{M}$ and $\mathrm{S}$ genes. 
Model II. An independent B gene controls only melanism (and iridescence), HW in both "melanic" and "non-melanic" broods being a product of the same $A$ allele. The $B$ gene is expressed only on a HW $(\boldsymbol{A}-)$ background and has the pleiotropic effect of reducing its range of expression.

Model III. Melanic spotting (and iridescence) are pleiotropic effects of a third (top dominant) A locus allele which also produces a high score for hindwing white.

Model IV. Similar to Model III, and possibly difficult to distinguish from it, melanism is controlled at a $B$ locus separate from A but tightly or absolutely linked to it. $A B$ in coupling phase would give melanism with high white (MHW), behaving as a pseudo-allele to $A b$ (HW) and $a b$ (OR).

Distinguishing between some of the models, given a second tier of epistasis superimposed upon the A-S basic (non-melanic) system, is not simple as they give predictions which overlap extensively. Nevertheless, each model provides some unique features.

We examine first the evidence for orderly segregation of melanism as a distinct character. There are 30 broods in which melanism was recorded for all offspring (Appendix 2, summary in table 4). Two crosses, G112 and G114, seem to be 1:0 for MHW, assuming that the six non-melanic offspring result from incomplete penetrance, estimated as $0 \cdot 932 \pm 0 \cdot 027$. Penetrance estimates for all broods lacking an expected (on Model I) non-melanic HW $(A-/ s s)$ class are in close agreement, $0.935 \pm$ 0.009 for individuals $(n=790)$ and $0.937 \pm 0.054$ for broods $(n=22)$; the latter are formally homogeneous $\left(\chi_{[21]}^{2}=30 \cdot 376 ; 0 \cdot 10>P>0 \cdot 05\right)$.

The 1:0 broods could result from crosses $B B \times$ $B B, B B \times B b$ and $B B \times b b$ (Models I and II), all of which give a 1:0 expectation for melanism if the $B$ allele is dominant. Of the remaining 28 crosses (table 4$), 9$ best fit F2 $(B b \times B b$, but see below) and 17 are backcrosses $(B b \times b b)$ at the 1 per cent level and formally homogeneous $\left(\chi_{[16]}^{2}=\right.$ $17 \cdot 078 ; 0 \cdot 5>P>0 \cdot 3$ ). (Model III requires alleles $A^{m}$ and $a$ to be substituted for $B$ and $b$ respectively but does not alter the predictions). Two broods (G075, G099) are omitted from the analysis as clearly aberrant, being highly deficient of melanics. They fit no model and must be explained by one of the following: abnormally low penetrance of melanism; low expressivity and consequent misidentification of phenotypes; low fitness of (heterozygous) melanics; contamination. The latter is most improbable on this scale. The expressivity of melanism is undoubtedly variable and the character is sometimes barely detectable: some "non-melanics" in broods G075 and G099 may be misidentified. Two extremes are shown in fig. 1: a heavy melanic $b l w / 5 M$ (No. 11), which is probably homozygous ( $B B$ or $A^{m} A^{m}$ ) and a brw/5M (melanic immima-alcippoides) in which the black scales are scarcely visible (No. 13). However, low viability in these broods is an additional possibility.

There is in fact good evidence for low viability in homozygous melanics. Six probable F2 broods best fit a 2:1 hypothesis: the nine tabulated F2s (3:1 and $2: 1$ in Appendix 2) fit an overall 2:1 hypothesis in all respects $\left(\chi^{2}\right.$ for total progeny $=$ $0 \cdot 272 ; \sum \chi_{[9]}^{2}$ for broods $=11 \cdot 544 ; \quad \chi_{[9]}^{2}$ for heterogeneity $=11 \cdot 272 ; \quad 0 \cdot 20>P>0 \cdot 10)$. The melanism gene is not however itself a recessive lethal as three of the nine F2s (G093, G101, G121) fit 3:1 closely. Moreover, we bred transvestites, which are interpreted as the homozygous phenotype, and the two 1:0 broods must have at least one homozygous parent. It is clear though that in a larger sample heterogeneity would be expected to show up in F2 segregations for melan-

Table 4 Segregations for melanic spotting in 30 "melanic" broods

\begin{tabular}{llllrl}
\hline Segregation & $\begin{array}{l}\text { Number of } \\
\text { broods }\end{array}$ & $\begin{array}{l}\text { Number of } \\
\text { offspring }\end{array}$ & \multicolumn{2}{c}{ Melanic spotting } & \multicolumn{2}{l}{$\begin{array}{l}\chi_{[1]}^{2} \\
\text { Total } \\
\text { progeny }\end{array}$} \\
\hline $1: 0$ & 2 & 88 & $82^{*}$ & 6 & - \\
$3: 1$ and $2: 1$ & 9 & 664 & 449 & 215 & $0 \cdot 272 \dagger$ \\
$1: 1$ & 17 & 718 & 335 & 383 & $3 \cdot 209 \ddagger$ \\
$1: 1 \S$ & 19 & 911 & 379 & 532 & $25 \cdot 696^{* * *}$ \\
\hline
\end{tabular}

* Penetrance is $0.932 \pm 0.027$.

$\dagger$ for $2: 1 ; \sum \chi_{[9]}^{2}$ for broods $=11 \cdot 544,0 \cdot 30>P>0 \cdot 20 ; \chi_{[8]}^{2}$ for heterogeneity $=11 \cdot 272,0 \cdot 20>P>0 \cdot 10 \cdot \chi^{2}$ for $3: 1=19 \cdot 285 ; P<0.001$.

$\ddagger \sum \chi_{[17]}^{2}$ for broods $=20 \cdot 287,0 \cdot 30>P>0 \cdot 20 ; \chi_{[16]}^{2}$ for heterogeneity $=17 \cdot 078,0 \cdot 50>P>0 \cdot 30$.

$\$$ Including broods G075 and G099 (see text).

*** $P<0.001$. 
Table 5 Expected ratios of phenotypes for high white (HW): low white and orange (LW/OR) and for melanic (M): non-melanic (NM) in "melanic" broods segregating at the A, B and S loci with epistasis (Model 1)

\begin{tabular}{|c|c|c|c|c|c|c|c|}
\hline \multirow{2}{*}{\multicolumn{2}{|c|}{ Segregation at }} & \multicolumn{6}{|c|}{ Segregation at A locus } \\
\hline & & \multicolumn{2}{|l|}{$1: 0$} & \multicolumn{2}{|l|}{$3: 1$} & \multicolumn{2}{|l|}{$1: 1$} \\
\hline $\begin{array}{l}\text { B } \\
\text { locus }\end{array}$ & $\begin{array}{l}\mathrm{S} \\
\text { locus }\end{array}$ & HW: LW/OR & $\mathrm{M}: \mathrm{NM}$ & HW: LW/OR & $\mathrm{M}: \mathrm{NM}$ & HW: LW/OR & $\mathrm{M}: \mathrm{NM}$ \\
\hline $3: 1$ & $1: 0$ & $3: 1^{*}$ & $3: 1$ & $13: 3^{*}$ & $3: 1$ & $3: 1^{*}$ & $3: 1$ \\
\hline $1: 1$ & $1: 0$ & $1: 1$ & $1: 1$ & $5: 3$ & $1: 1$ & $1 ; 1$ & $1: 1$ \\
\hline $3: 1$ & $3 ; 1$ & $13: 3^{*}$ & $3: 1$ & $51: 13^{*}$ & $3: 1$ & $25: 7^{*}$ & $3: 1$ \\
\hline $1: 1$ & $3: 1$ & $5: 3$ & $1: 1$ & $19: 13$ & $1: 1$ & $9: 7$ & $1: 1$ \\
\hline $3: 1$ & $1: 1$ & $7: 1^{*}$ & $3: 1$ & $27: 5^{*}$ & $3: 1$ & $3: 1^{*}$ & $3: 1$ \\
\hline $1: 1$ & $1: 1$ & $3: 1$ & $1: 1$ & $11: 5$ & $1: 1$ & $5: 3$ & $1: 1$ \\
\hline $3: 1$ & $0: 1$ & $1: 0$ & $3: 1$ & $15: 1^{*}$ & $3: 1$ & $7: 1^{*}$ & $3: 1$ \\
\hline $1: 1$ & $0: 1$ & $1: 0$ & $1: 1$ & $7: 1$ & $1: 1$ & $3: 1$ & $1: 1$ \\
\hline
\end{tabular}

* The HW class will be reduced when the M:NM segregation is $2: 1$ (see text).

ism. Any reduced viability among homozygous melanics will also affect the $\mathrm{HW}: \mathrm{LW} / \mathrm{OR}$ ratios (below) and must account for some of the heterogeneity found.

Predicted segregations for $\mathrm{HW}$ : LW/OR under Model I are shown in table 5 and the fit of each "melanic" brood to this Model is given in Appen$\operatorname{dix} 2$. The essence of the Model is that the B gene is epistatic to both $A$ and $S$ so that all $B$-butterflies are $\mathrm{MHW}$. Segregation at the $\mathrm{A}$ and $\mathrm{S}$ loci in a $b b$ class is expected to follow the same principles as in non-melanics. All $40 \mathrm{HW}$ : LW/OR segregations are a satisfactory fit to Model $\mathrm{I}$ at the 1 per cent level. Furthermore, the subsidiary segregations such as $\mathrm{M}: \mathrm{NM}, \mathrm{MHW}: \mathrm{HW}$ and LW:OR, which cannot be predicted with precision on account of variable penetrance, expressivity, epistasis and viability ( $M: N M$ only), generally conform to expectation. Incidentally, we are not suggesting that a fit to complex three-locus segregations such as $19: 13,25: 7$ or $27: 5$ is in any way definitive: all these broods satisfy some of the simpler expectations (table 1(b)). However, the overall fit of the data to Model I is impressive.

Model II is intuitively attractive. However, when the combined segregations for $\mathrm{HW}: \mathrm{LW} / \mathrm{OR}$ and $\mathrm{M}: \mathrm{NM}$ are examined, many broods decisively reject the hypothesis. In particular, with $3: 1$ or $1: 1$ segregations at the $A$ locus, the $M: N M$ segregation must be one of $9: 7,3: 5$ or $1: 3$. We accept that $9: 7$ is inseparable from $1: 1$ on our sample sizes, but $3: 5$ and $1: 3$ ratios were not obtained (except for the anomalous G075 which fortuitously fits 1:3). Moreover, Model II requires that 28 of the 30 "melanic" broods are 1:0 at the A locus, which in turn implies that almost all the OR butter- flies are $A-/ S-$. This is a most improbable interpretation of the B2 and B3 broods, many of which lack LW. There are therefore good grounds for discarding Model II.

Model $1 \mathrm{Il}$ invokes a third, top dominant, allele at the A locus, which we call $A^{m}$. After eliminating all complex three-locus ratios, the expected segregations for $\mathrm{HW}: \mathrm{LW} / \mathrm{OR}$ under this two-locus hypothesis $(1: 0,3: 1,13: 3,7: 1,5: 3,9: 7$ and $1: 1)$ are remarkably similar to those for Model I (table 5, Appendix 2). All the broods can be satisfactorily classified (fig. 3) by the same method used for the "non-melanic" broods. If melanism is a pleiotropic effect of an A locus allele, it is clear that a two locus model with three alleles at $\mathrm{A}$ and two at $\mathrm{S}$ can also accomodate the data on the basis of a simple extension of the "non-melanic" model (table 2). In this case, the occurrence of nonmelanic HW in "melanic" broods results from segregation of $A$ and $A^{m}$ alleles, while broods lacking LW segregate for $A^{m}$ and $a$. Moreover, the absence of melanism in LW is expected if $\boldsymbol{A}$ is suppressed by $S$ but $A^{m}$ is not.

Model IV involves close linkage in coupling or pseudo-allelis $\mathrm{m}$ between the genes controlling HW and melanism. It predicts similar or identical breeding results to Model III and is therefore difficult to rule out. However, unless linkage is absolute, rare recombinants are expected, especially considering the large numbers of offspring raised. Occasional melanics with orange hindwings should occur whereas none were produced. The $6 \mathrm{LW}$ melanics (G116, G120) provide no evidence for crossover as they can be either $A-/ B-/ S-$ (Model III) or $A B / / a b / S-$ (Model IV). 
A firm choice between Models I and III cannot be made on statistical grounds though Model I probably accounts for the fine details of phenotype distribution in individual broods marginally better. The only two broods (G075 and G099) which reject Model I (for M:NM) equally reject Model III. On genetical grounds we marginally prefer Model I to Model III. The postulated $A^{m}$ allele would be a somewhat curious gene, producing black, white and iridescence simultaneously. Moreover, Model III requires that $S$ is epistatic to $A$ but hypostatic to $A^{m}$, an unusual relation between loci for which it is difficult to devise parsimonious explanations at either the molecular or population levels. The modus operandi of the melanism gene is probably as a switch for the expression of male colour pattern genes in females. If this is correct, its mode of action must be quite different from the relatively simple colour switch controlled by the A gene and it is more likely to be at a different locus.

\section{Epistatic interactions of the $A, S$ and $M$ loci}

Edmunds (1969) demonstrated a correlation between white hindwings and intermediate (op$b r w)$ forewings in immima $(A a / \mathrm{mm})$ butterflies. We confirm this and suggest its cause to be an epistatic effect of a gene for hindwing white, leading in extreme cases to misclassification of $\mathrm{M}$ locus genotypes (Smith and Gordon, 1987). We are now able to examine epistasis in more detail following on from the genetic hypothesis proposed in table 2.

The epistatic interactions of the $\mathrm{A}$ and $\mathrm{S}$ loci on the forewing apex of inaria $(a a / \mathrm{mm})$ and immima $(A a / \mathrm{mm})$ butterflies from "non-melanic" broods are shown in table 6 . Ideally comparisons should be between $a a$ and $A$ - butterflies but, because orange hindwings result from both $A-/ S-$ and $a a /--$ genotypes, it is impossible to identify the latter with certainty. However, aa genotypes must predominate in broods where hindwing white is entirely absent from both mothers and progeny: ten such broods are identified and the distribution of their forewing phenotypes is shown in the first row of table 6 . OR progeny of A1-A6 (second row in table 6) are a mixture of $a a /--$ and $A-/ S-$ in unknown proportions, while A1-A6 progeny scoring 1-3 for hindwing (third row) must be almost entirely $A-/ S-$. Lastly, nearly all HW A1-A6 progeny (fourth row) must be $A-/$ ss. The shift in forewing pattern that results from presence of the $A$ allele is dramatic and obvious.

This shift is analysed in table 7. Epistatic effects are examined separately for apical ground colour $(o, o r, b r)$ and for colour of the subapical band $(o, p$ or $w)$. It is clear that both are strongly influenced by the A locus, with orange scales being replaced by black and white respectively when the $A$ allele is present. However, the $\mathrm{S}$ locus affects the two components of apical pattern differently. Comparison between LW and $\mathrm{HW}$ in A1-A6 brood classes (table 7) shows that the $S$ allele reduces white in the subapical band $\left(\chi_{[1]}^{2}=66.080 ; P<\right.$ $0.001)$ but has no detectable effect on black in the ground colour of the apex $\left(\chi_{[1]}^{2}=0 \cdot 226\right)$. Thus at least one of the effects of the $A$ allele is immune to suppression by $S$.

The melanism gene has similar but more extreme effects on immima and inaria forewing phenotypes which it converts to a misippus (blw) or near-misippus (brw, brp) pattern. Of 227 recognizable melanic immima/inaria, 87.7 per cent are $b r w$, many barely distinguishable from $b l w$, the rest being brp. No melanic oo, op, ow or bro butterflies were recorded. Table 8 shows that conversion often goes all the way to a full misippus pattern. Segregations for M locus phenotypes in "melanic" broods

Table 6 Epistatic effects of the $A$ allele on immima/inaria phenotypes

Phenotypes of immima/inaria $(\mathrm{mm})$ progeny

\begin{tabular}{|c|c|c|c|c|c|c|c|c|}
\hline \multirow{2}{*}{$\begin{array}{l}\text { Brood } \\
\text { types }\end{array}$} & \multirow{2}{*}{$\begin{array}{l}\text { Hindwing } \\
\text { score }\end{array}$} & \multicolumn{6}{|c|}{ Forewing } & \multirow[b]{2}{*}{$N$} \\
\hline & & $o o$ & $o p$ & ow & bro & $b r p$ & $b r w$ & \\
\hline all orange & $\theta(\mathrm{OR})$ & $67 \cdot 4$ & $12 \cdot 9$ & $0 \cdot 6$ & $11 \cdot 4$ & $4 \cdot 5$ & $3 \cdot 4$ & 178 \\
\hline $\mathrm{A} 1, \mathrm{~A} 3-\mathrm{A} 6^{*}$ & $\theta(\mathrm{OR})$ & $29 \cdot 0$ & $16 \cdot 7$ & 0.6 & $24 \cdot 2$ & $26 \cdot 7$ & $2 \cdot 8$ & 472 \\
\hline $\mathrm{A} 1-\mathrm{A} 6+$ & $1-3(\mathrm{LW})$ & $10 \cdot 3$ & $23 \cdot 9$ & $2 \cdot 0$ & $9 \cdot 6$ & $36 \cdot 7$ & $17 \cdot 5$ & 406 \\
\hline $\mathrm{A} 1-\mathrm{A} 6+$ & $4-8(\mathrm{HW})$ & $4 \cdot 1$ & $26 \cdot 9$ & $7 \cdot 6$ & $0 \cdot 0$ & $20 \cdot 3$ & $41 \cdot 1$ & 197 \\
\hline
\end{tabular}

Notes:

Figures give the percentage of butterflies in each forewing class.

* No orange hindwings were recorded for immima/inaria in A2 broods.

$\dagger$ immima/inaria was not recorded from A7 broods. 
Table 7 Analysis of the data.in table 6

\begin{tabular}{|c|c|c|c|c|c|c|c|}
\hline \multirow{3}{*}{$\begin{array}{l}\text { Brood } \\
\text { types }\end{array}$} & \multirow{3}{*}{$\begin{array}{l}\text { Hindwing } \\
\text { score }\end{array}$} & \multicolumn{5}{|c|}{ Colour of forewing apex } & \multirow[b]{3}{*}{$N$} \\
\hline & & \multicolumn{2}{|c|}{ Ground colour } & \multicolumn{3}{|c|}{ Sub-apical band } & \\
\hline & & $o$ & $b r$ & $o$ & $p$ & $w$ & \\
\hline all orange & $O(\mathrm{OR})$ & $80 \cdot 9$ & $19 \cdot 1$ & $78 \cdot 7$ & $17 \cdot 4$ & $3 \cdot 9$ & 178 \\
\hline $\mathrm{A} 1, \mathrm{~A} 3-\mathrm{A} 6$ & $O(\mathrm{OR})$ & $46 \cdot 4$ & $53 \cdot 6$ & $53 \cdot 2$ & $43 \cdot 4$ & $3 \cdot 4$ & 472 \\
\hline $\mathrm{A} 1-\mathrm{A} 6$ & $1-3(\mathrm{LW})$ & $36 \cdot 2$ & $63 \cdot 8$ & $20 \cdot 0$ & $60 \cdot 6$ & $19 \cdot 5$ & 406 \\
\hline Al-A6 & $4-8(\mathrm{HW})$ & $38 \cdot 6$ & $61 \cdot 4$ & $4 \cdot 1$ & $47 \cdot 2$ & $48 \cdot 7$ & 197 \\
\hline$x^{2}$ & & \multicolumn{2}{|c|}{$106 \cdot 813$} & \multicolumn{3}{|c|}{$450 \cdot 668$} & \\
\hline df & & \multicolumn{2}{|c|}{3} & \multicolumn{3}{|c|}{6} & \\
\hline$P$ & & \multicolumn{2}{|c|}{$<0.001$} & \multicolumn{3}{|c|}{$<0.001$} & \\
\hline
\end{tabular}

are heavily distorted in favour of blw (misippus) forewings, especially amongst HW offspring. Mendelian segregations at the $M$ locus could be consistently recognized only among non-melanic OR or LW progeny which lack the melanism gene. Moreover, in one brood (G114), the female parent was phenotypically misippus, yet had all immima (brw and brp) offspring: its genotype must have been $A a / m m$ despite the blw forewings.

Thus both $A$ and $B$ (or $A^{m}$ ) alleles shift forewing pattern from inaria to misippus. These epistatic effects in the forewing are expressed only in $m m$ butterflies. The effect of the $A$ allele on the subapical band is partially suppressed when the $S$ allele is also present but its effect on apical ground colour is unaffected. Effects of the melanism gene are unsupressed and more extreme so that many $\mathrm{mm}$ butterflies are unrecognizable as immima/inaria when melanism is present. Forewing phenotypes of $\mathrm{mm}$ butterflies may therefore range from $o o$ all the way to $b l w$ and are largely controlled by the A locus with the $S$ locus playing a minor role through modification of the subapical band.

\section{DISCUSSION}

Sex linkage can readily be dismissed for all the loci identified. First, Y-linkage as found, for example in Papilio glaucus L. (Clarke and Sheppard, $1959 ; 1962$ ), is characterised (in Lepidoptera) by inheritance exclusively in the female line and is easily ruled out for $H$. misippus. Second, in orthodox X-linkage, only $1: 1$ segregations are expected in XY (female) progenies; 3:1 ratios, which occurred for all loci, are impossible. A third possibility, partial sex-linkage (for a gene located on a segment homologous to both $\mathrm{X}$ and $\mathrm{Y}$ chromosomes), is also limited to $1: 1$ expectations if only one sex is scored. We are therefore confident that none of the possible sex linkage mechanisms can explain the data and all three loci must be autosomal but sex-controlled to the female, as in the closely related species $\mathrm{H}$. bolina (Clarke and Sheppard, 1975).

Inheritance of hindwing colour in $\mathrm{H}$. misippus is complex and hypotheses other than those we have examined are possible. However, points in

Table 8 Evidence for distortion of $\mathrm{M}$ locus segregations by the melanism gene

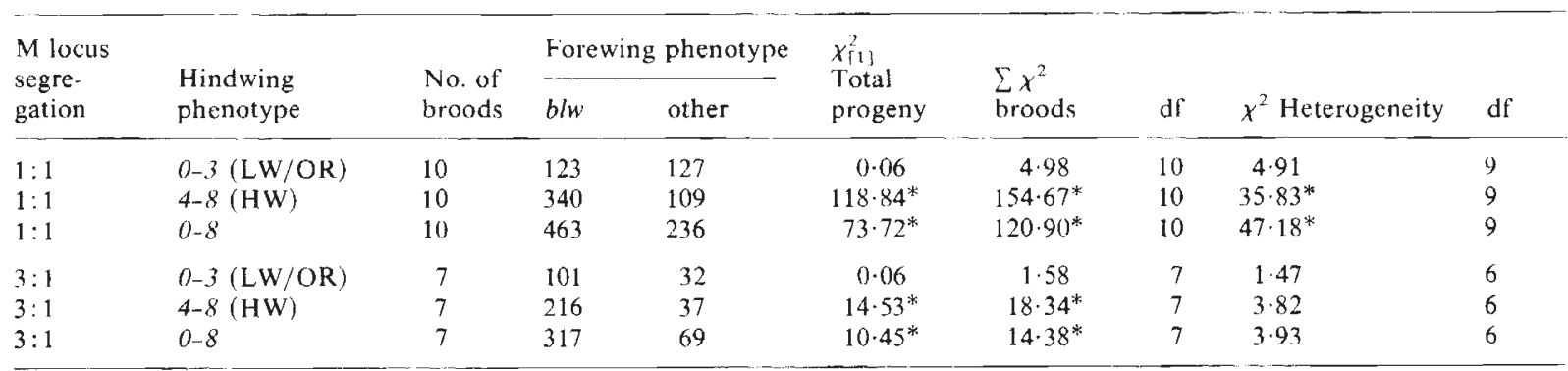

All individual broods fit the predicted $M$ locus segregations if only the LW/OR progeny are considered.

* Indicates values of $\chi^{2}$ for which $P \leqslant 0.05$. 
favour of both the A-S Model for non-melanics, the B Model for melanism and the A-M Model for the forewing are their relative simplicity and capacity to account for such diverse results. Moreover, most of their features are well founded, including evidence for major gene effects on presence and quantity of hindwing white, dominance and epistasis of the melanism gene, epistatic interaction between $\mathrm{A}$ and both $\mathrm{M}$ and $\mathrm{S}$ loci and genetic redundancy in the production of both fore- and hindwing phenotypes. Much of the following discussion is based on these assertions and avoids the assumption that our preferred models are correct in every particular.

A conventional interpretation of the dominance order at the A locus would suggest that the ancestral female hindwing was orange and $A$ is the more recent allele (following the reasoning of Haldane, 1924, explored further by Turner, 1977 and Clarke et al. 1985). However, as Clarke and his colleagues point out, a substantial caveat is necessary in any individual case. In the first place, correlation of dominance and recent evolution, first predicted by Fisher (1930), is statistical and exceptions are also predicted: $A$ and/or $a$ could have drifted to, or been founded at, present frequencies or high enough frequencies to be selected for their recessive effects, although this seems unlikely. Secondly, dominance can be modified (e.g. by hybridization) and subsequent reversals of dominance will not correlate with mutation sequence. Thirdly, alleles which have multiple effects may also have multiple states of dominance. For example, $\boldsymbol{A}$ has three visible effects on colour pattern. One (white hindwing patch) is fully dominant, the second (white sub-apical band in the forewing) is almost dominant while the third (black forewing apex) has only partial and variable dominance. At least six effects of the melanism gene ( $B$ or $A^{m}$ ) have been noted, high white hindwing and forewing sub-apical band being dominant, black forewing apex and hindwing melanism semi-dominant, while iridescence and forewing melanism are recessive. Where an array of distinct phenotypic effects, ranging from dominant to recessive, stem from a single allele, each character state may have evolved independently, through gradual accumulation of modifiers, advantageous effects acquiring dominance, and disadvantageous ones becoming recessive (Fisher, 1930; Sheppard, 1967). Moreover, an apparently recessive allele may have been selected for undetected dominant effects and may therefore be the most recently evolved.
So far we have considered the A locus to be the site of a single gene. There are in fact two possibilities which are not mutually exclusive: (1) it is a supergene composed of genes coding separately for characters such as hindwing colour distribution, forewing apex and sub-apical region; (2) it is a regulatory switch gene controlling the expression of unidentified structural genes for wing colour. Either hypothesis could explain the multiple and varied effects of the A locus alleles and, if the melanic gene is $A^{m}$, their different epistatic relations with the $\mathrm{S}$ locus.

However, the second is in many ways the more economical and probable explanation. Our detailed study of the effects of the $S$ gene suggest that it suppresses white in both fore- and hindwings but has no effect on black in either wing. The fact that the $S$ allele does not suppress white (or black) in melanics supports the B gene model rather than the $A^{m}$ model. The $\mathrm{B}$ gene is probably an independent regulatory gene which switches on some of the genes which control male colour pattern. Clarke et al. (op. cit.) point out that a new male-like form may be added to a female-limited polymorphism in precisely this manner, by allowing autosomal male colour pattern genes to be switched on instead of off in XY butterflies. Given the dominance of the B gene and its epistasis over the $\mathrm{A}, \mathrm{M}$ and $\mathrm{S}$ loci, this may well have happened in $H$. misippus. Compared with the male-like form naresi of the closely related, polymorphic and mimetic species $H$. bolina, melanic alcippoides is much less male-like, at least in the heterozygote. Furthermore, in marked contrast to the latter, naresi, which Clarke and Sheppard (1975) considered to be the ancestral female form, is recessive to the mimetic forms at two or three loci.

Vane-Wright (1984) has suggested that transvestite females quickly attract the attention of territorial males and are therefore sexually selected. Although the $B\left(A^{m}\right)$ allele could be selected on such a basis, it is important to appreciate that few melanic butterflies could be considered transvestite. Melanism is often feebly expressed in heterozygotes and the butterflies more resemble non-melanic alcippoides than males. However, the homozygote (fig. 1, No. 11), which has never been recorded in the wild (it would be easily dismissed as a male and overlooked), is truly transvestite.

In West Africa, where the D. chrysippus model is monomorphic for the white hindwinged form alcippus, the heterozygous melanics look convincing mimics. (A majority of our bred butterflies must have been heterozygotes as 19 of the 30 
"melanic" broods are backcrosses for melanism and the F2 broods are deficient in (homozygous) melanics). D. chrysippus is polymorphic for brown or orange ground colour throughout the region (Clarke, Sheppard and Smith, 1973; Gordon, 1984; Smith, Shoesmith and Smith, 1988) and the less extreme (heterozygous) melanic alcippoides, which may have black and orange scales intermingled to give an overall brownish effect, are undoubtedly good mimics of brown alcippus. Furthermore, transvestite melanics, which are probably homozygotes, are fair mimics of Amauris niavius, a widespread danaid model, mainly in forest and wooded savannah. It is possible that the "transvestites" originated as Amauris mimics.

There is a melanic specimen $(b / w / 5 M)$, almost certainly a heterozygote $(A-/ B b / M-/--$ or $\left.A^{m}-M-/--\right)$, in the Nairobi Museum, caught in 1939 at Katera in Uganda, where alcippus is probably not uncommon (Owen and Chanter, 1968). However, a mimetic relationship with $D$. chrysippus cannot explain the presence of the melanism gene in Zimbabwe, where alcippus is altogether absent: the Bulawayo Museum has a melanic specimen (brw/5M), the only wild melanic immima-alcippoides $\left(A \mathrm{a} / \mathrm{Bb} / \mathrm{mm}-\right.$ - or $\left.A^{m} \mathrm{a} / \mathrm{mm} /--\right)$ recorded, caught in Bulawayo in 1979. The East and Central African melanism records suggest a widespread distribution for the melanism gene although it is rare everywhere. In Ghana, only two recognizably melanic specimens, both heterozygotes, were caught in a sample of over 2000 wild butterflies. A gene frequency as low as $5 \times 10^{-4}$ might even be maintained by recurrent mutation. As neither the Ghana melanics nor the two museum specimens were conspicuously male-like, sexual selection for a transvestite colour pattern is even more problematical than natural selection for mimicry. Furthermore, the commonest modifiers of melanism in Ghana produce mimicry to $D$. chrysippus $\mathrm{f}$. alcippus rather than transvestism: were the melanism gene not so rare, this would suggest that it is better to be a mimic than a transvestite.

The epistatic relations between the $\mathrm{A}$ and $\mathrm{M}$ loci, on the one hand, and the A and S loci on the other, function as alternative systems for the production of misippus forewings or orange hindwings respectively. Epistasis of $A$ is incomplete and highly variable in the $A a / m m$ genotype (Smith and Gordon, 1987). In $M$ - butterflies, epistasis of $A$ and $A^{m}$ or $B$ are redundant as the dominant $M$ allele produces a $b l w$ forewing irrespective of genotype at the $\mathrm{A}, \mathrm{B}$ or $\mathrm{S}$ loci. Conclusive proof of this is only gained from those progenies (M152, Smith and Gordon, 1987) or part-progenies (B2 and B3, fig. 3) which are all orange ( $a a)$ but segregate for misippus $(M-)$ and inaria $(\mathrm{mm})$ forewing. There are thus three genetic systems which produce or approximate the misippus forewing, $B$ - or $A^{m}-, A-/ s s$ and $M-$. Moreover, there are two systems $\left(B-\right.$ or $A^{m}-$ and $\left.A-/ s s\right)$ producing a large white patch in the hindwing and two systems ( $a a$ and $S_{-}$) which replace the white with orange. The phenotype codes with their probable genotypes and the nomenclature of non-melanic morphs are summarised in table 3.

Selection for the $M$ allele may originally have been as a modifier of dominance at the A locus. Whereas $A a / \mathrm{mm}$ butterflies probably always have immima (and non-mimetic) forewings, the $A A / \mathrm{mm}$ genotype usually, and perhaps always, has a blw forewing. Thus, $M$ not only enhances dominance of $A$ over its allele but also improves mimicry significantly in $A a / M-$ compared to $A a / m m$ heterozygotes. However it seems that further selection on $M$ has produced a non-specific modifier (Turner, 1977) which confers a misippus forewing on all genotypes. Alternatively, $M$ could have become established as an epistatic nonspecific modifier at a single step.

The $S$ allele has probably been selected as a modifier of the hindwing expression of $A$ which, through suppression of white, dramatically improves mimicry over that major part of the species range from which the alcippus form of the model is absent. Therefore, the $S$ allele answers the definition of an hypostatic specific modifier, a gene which influences the expression of a major switch gene by altering the phenotypic expression, not of all, but of a few particular genotypes (Turner, 1977).

It seems that we are dealing here with distinct genetic systems evolved in isolation from one another and that mimicry evolved independently on more than one occasion. Consider for a moment the situation in West Africa. All $A-/ s s$ and $B-$ or $A^{m}$ - butterflies are fair mimics of $D$. chrysippus f. alcippus, but the best mimic is $A-/ b b / M-/ s s$ $((A-/ M-/ s s)$ which is guaranteed both a blw forewing and extensive hindwing white without melanism. Optimal mimicry thus depends on a combination of genotypes at three or four independent, interacting loci but serviceable mimicry can be provided by the melanism gene alone. The rarity of this gene in Ghana, where the model is monomorphic, or even where it is common as in Uganda, and its rare occurrence way outside the range of the model, remain a challenge to our interpretation of the evolutionary genetics of this puzzling species. It is possible that the melanism 
gene has no status beyond that of a rare, recurrent mutant.

Finally, the genetic architecture of $H$. misippus demonstrates that hierarchical epistasis, with independent segregation at several autosomal loci, is a major evolutionary alternative to the supergene, as found for example in the Papilios, Primula and Cepaea, or multiple alleles as in Adalia bipunctata and Biston betularia, as a mechanism controlling a visual or structural polymorphism.

Acknowledgements We thank Sir Cyril Clarke, FRS, Mr R. I. Vane-Wright and Dr D. F. Owen for their helpful comments on drafts of this paper and the referee, John Barrett for his perceptive suggestions for improvement. Mr Derek Whiteley drew fig. 1.

\section{REFERENCES}

BAILEY, N. T. J. 1959. Statistical Methods in Biology. London, English Universities Press.

BERNARDI, G. 1963. Quelques aspects geographique du mimétisme chez les Lépidoptères. Proceedings of the XVIth. Congress of Zoology, Washington, 4, 161-166.

BERnARDi, G. 1974. Polymorphisme et mimétisme chez les Lepidopteres Rhopaloceres. Memoires du Societé zoologique de la France, 37, 129-168.

Clarke, C. A. Clarke, C. M. M., COllins, S. C., Gill. A. C. L. AND TURNER, J. R. G. 1985. Male-like females, mimicry and transvestism in butterflies. Systematic Entomology, 10, 257-283.

CLARKE, C. A. AND SHEPPARD, P. M. 1959. The genetics of some mimetic forms of Papilio dardanus and Papilio glaucus. Journal of Genetics, 56, 236-260.

CLARKE, C. A. AND SHEPPARD, P. M. 1962. The genetics of the mimetic butterfly Papilio glaucus. Ecology, 43, 159-161.

CLARKE, C. A. AND SHEPPARD, P. M. 1975. The genetics of the mimetic butterfly Hypolimnas bolina (L.). Philosophical Transactions of the Royal Society of London, series B, 272, 229-265.

CLARKE, C. A. SHEPPARD, P. M. AND SMITH, A. G. 1973. The genetics of fore- and hindwing colour in crosses between Danaus chrysippus from Australia and Sierra Leone (Danaidae). Journal of the Lepidopterists' Society, 27, 73-77.

EDMUNDS, M. 1969. Polymorphism in the mimetic butterfly Hypolimnas misippus L. in Ghana. Heredity, 24, 281-302.

FISHER, R. A. 1930. The Genetical Theory of Natural Selection. Oxford University Press.
GORDON, I. J. 1982. The Biology of Danaus chrysippus (Lepidoptera: Danaidae) and its Mimics in Ghana. Ph.D. Thesis, University of Ghana.

GORDON, 1. J. 1984. Polymorphism of the tropical butterfly Danaus chrysippus L. in Africa. Heredity, 53, 583-593.

GORDON, I. J. 1987. Natural selection for rare and mimetic colour pattern combinations in wild populations of the diadem butterfly, Hypolimnas misippus L. Biological Journal of the Linnean Society, 31, 1-23.

HALDANE, J. B. S. 1924. A mathematical theory of natural and artificial selection. Part 1. Transactions of the Cambridge Philosophical Society, 33, 19-41.

OWEN, D. F. AND CHANTER, D. O. 1968. Population biology of tropical African butterflies. 2. Sex ratio and polymorphism in Danaus chrysippus L. Revue de zoologie et de botanique africaines, 78, 81-97.

PIERRE, J. 1973. Étude d'un cycle mimétique ayant Danaus chrysippus (Linné) (Lepidoptère, Danaidae) pour modele et Hypolimnas misippus (Linné) pour mime. Archives de zoologie expérimentale et générale, 114, 73-96.

PIERRE, J. 1980. Variation geographique du polymorphisme et du mimétisme de Danaus chrysippus et d'Hypolimnas misippus (Lepidoptères Rhopalocères) en Afrique et an Asie. Compte rendu des séances du Société biogéographique, 486, 179-187.

POulton, E. B. 1912. Comment on Col. Mander's paper. Proceedings of the Royal Entomological Society of London, 1912, vii-ix.

SHEPPARD, P. M. 1967. Natural Selection and Heredity, 3rd ed. London, Hutchinson.

SMITH, D. A. S. 1976. Phenotypic diversity, mimicry and natural selection in the African butterfly Hypolimnas misippus L. (Lepidoptera: Nymphalidae). Biological Journal of the Linnean Society, 8, 183-204.

SMITH, D. A. S. AND GORDON, I. J. 1987. The genetics of the polymorphic tropical butterfly Hypolimnas misippus: the classification of phenotypes and the inheritance of forms misippus and inaria. Heredity, 59, 467-475.

SMITH, D. A. S., SHOESMITH, E. A. AND SMITH, A. G. 1988. Pupal polymorphism in the butterfly Danaus chrysippus (L.): environmental, seasonal and genetic influences. Biological Journal of the Linnean Society, 33, 17-50.

TRIMEN, R. 1887. South African Butterflies: A Monograph of the Extra-Tropical Species. 1. London.

TURNER, J. R. G. 1977. Butterfly mimicry: the genetical evolution of an adaptation. In Hecht, M. K., Steere, W. C. and Wallace, B (eds) Evolutionary Biology, vol. 10. New York, Plenum Publishing Corporation, pp. 163-206.

UNAMBA, J. A. 1968. Ecological Genetics of the Butterfly Hypolimnas misippus. Ph.D. Thesis, University of Sierra Leone, Freetown.

VANE-WRIGHT, R. I. 1984. The role of pseudosexual selection in the evolution of butterfly colour patterns. In VaneWright, R. I. and Ackery, P. R. (eds) The Biology of Butterflies, Symposia of the Royal Entomological Society of London, No. 11, pp. 251-253. 
APPENDIX 1

"Non-melanic" broods of $\mathrm{H}$. misippus (female progeny only) which segregate for hindwing white 0-3:4-8 (LW/OR:HW)

\begin{tabular}{|c|c|c|c|c|c|c|c|}
\hline \multirow{2}{*}{$\begin{array}{l}\text { Brood } \\
\text { number }\end{array}$} & \multirow{2}{*}{$\begin{array}{l}\text { Maternal } \\
\text { phenotype }\end{array}$} & \multicolumn{3}{|c|}{ Hindwing phenotypes } & \multirow{2}{*}{$\begin{array}{l}\mathrm{H}_{0} \text { giving } \\
\text { best fit }\end{array}$} & \multirow[b]{2}{*}{$x^{2}$} & \multirow{2}{*}{$\begin{array}{l}\text { Frequency } \\
\text { distributior } \\
\text { (fig. 2) }\end{array}$} \\
\hline & & $\mathrm{LW} / \mathrm{OR}$ & HW & $N$ & & & \\
\hline G002 & $b l w / 8$ & 48 & 50 & 98 & $1: 1^{*}$ & 0.041 & A3 \\
\hline G041 & $b l w / 3$ & 35 & 41 & 76 & $1: 1^{*}$ & 0.474 & A3 \\
\hline G057 & $b l w / 0$ & 33 & 43 & 76 & $1: 1^{*}$ & 0.439 & A3 \\
\hline G063 & $b / w / 2$ & 48 & 47 & 95 & $1: 1^{*}$ & 0.011 & A3 \\
\hline G067 & $b l w / 2$ & 6 & 15 & 21 & $1: 1^{*}$ & $3 \cdot 857$ & A3 \\
\hline G081 & $b l w / 0$ & 33 & 26 & 59 & $1: 1$ & 0.831 & A3 \\
\hline G084 & $b r w / 1$ & 11 & 9 & 20 & $1: 1$ & $0 \cdot 200$ & A3 \\
\hline G004 & $b l w / 5$ & 9 & 2 & 11 & $3: 1$ & 0.273 & A5 \\
\hline G024 & $b / w / 3$ & 28 & 11 & 39 & $3: 1$ & $0 \cdot 217$ & A5 \\
\hline G027 & $b l w / 1$ & 87 & 22 & 109 & $3: 1$ & 1.349 & A5 \\
\hline G042 & $o p / 2$ & 41 & 18 & 59 & $3: 1$ & 0.955 & A5 \\
\hline G052 & $b l w / 0$ & 105 & 41 & 146 & $3: 1$ & 0.740 & A5 \\
\hline G055 & $b / w / 0$ & 71 & 31 & 102 & $3: 1$ & 1.581 & A5 \\
\hline G096 & $b l w / 3$ & 40 & 14 & 54 & $3: 1$ & 0.025 & A5 \\
\hline G016 & $o p / 2$ & 35 & 4 & 39 & $7: 1$ & $0 \cdot 179$ & A7 \\
\hline G022 & $o p / 5$ & 31 & 2 & 33 & $7: 1$ & $1 \cdot 251$ & A7 \\
\hline G019 & $b l w / 5$ & 109 & 56 & 165 & $5: 3^{*}$ & 0.892 & A4 \\
\hline G044 & $b l w / 7$ & 12 & 6 & 18 & $5: 3$ & 0.133 & A4 \\
\hline G060 & $o p / 4$ & 46 & 34 & 80 & $5: 3$ & 0.853 & A4 \\
\hline G098 & $b l w / 1$ & 68 & 35 & 104 & $5: 3$ & 0.544 & A4 \\
\hline G105 & $b l w / 4$ & 54 & 32 & 86 & $5: 3$ & 0.003 & A4 \\
\hline G017 & $o p / 1$ & 103 & 27 & 130 & $13: 3$ & 0.348 & A6 \\
\hline G023 & blw $/ 0$ & 15 & 3 & 18 & $13: 3$ & 0.051 & A6 \\
\hline G083 & $b l w / 2$ & 65 & 9 & 74 & $13: 3$ & $2 \cdot 108$ & A6 \\
\hline
\end{tabular}

* Brood fits only this hypothesis $(P \leq 0 \cdot 01)$. 
APPENDIX 2

Segregations (Model I) for 4-8 (HW) :0-3 (LW/OR) and melanic (M): non-melanic (NM) in 42 "melanic" female progenies of $\mathrm{H}$. misippus

\begin{tabular}{|c|c|c|c|c|c|c|c|c|c|c|c|}
\hline \multirow{2}{*}{$\begin{array}{l}\text { Brood } \\
\text { number }\end{array}$} & \multirow{2}{*}{$\begin{array}{l}\text { Maternal } \\
\text { phenotype }\end{array}$} & \multicolumn{6}{|c|}{ Segregation for $\mathrm{HW}$ : LW/OR } & \multicolumn{4}{|c|}{ Segregation for $M: N M$} \\
\hline & & HW & $\mathrm{LW} / \mathrm{OR}$ & $N$ & $\mathrm{H}_{0}$ & class & $\chi^{2}$ & $\mathrm{M}$ & NM & $\mathrm{H}_{0}$ & $\chi^{2}$ \\
\hline G114 & $b l w / 5 M$ & 35 & 1 & 36 & $1: 0$ & B1 & - & 35 & 1 & $1: 0$ & - \\
\hline G020 & $b l w / 5$ & 18 & 21 & 39 & $1: 1$ & B3 & 0.231 & ns & - & - & - \\
\hline G049 & $b l w / 5 M$ & 17 & 22 & 39 & $1: 1$ & B3 & 0.641 & 17 & 22 & $1: 1$ & 0.641 \\
\hline G077 & $0 o / 0$ & 26 & 31 & 57 & $1: 1$ & B3 & 0.439 & 24 & 33 & $1: 1$ & $1 \cdot 421$ \\
\hline G109 & $b l w / 5 M$ & 42 & 38 & 80 & $1: 1$ & B3 & $0 \cdot 200$ & ns & - & - & - \\
\hline G113 & $b l w / 5 M$ & 24 & 24 & 48 & $1: 1$ & B3 & 0.000 & ns & - & - & - \\
\hline G116 & $b r p / 0$ & $7^{*}$ & 11 & 18 & $1: 1$ & B3 & 0.889 & $7^{*}$ & 11 & $1: 1$ & 0.889 \\
\hline G117 & $b l w / 5 M$ & 16 & 18 & 34 & $1: 1$ & B3 & $0 \cdot 118$ & 14 & 20 & $1: 1$ & 1.059 \\
\hline G119 & $b l w / 5 M$ & 7 & 6 & 13 & $1: 1$ & B3 & 0.077 & 7 & 6 & $1: 1$ & 0.077 \\
\hline G072 & $b l w / 4 M$ & 29 & 34 & 63 & $1: 1$ & B4 & 0.397 & 26 & 37 & $1: 1$ & 1.921 \\
\hline G080 & $b l w / 5$ & 34 & 28 & 62 & $1: 1$ & B4 & 0.581 & ns & - & - & - \\
\hline G082 & $b r p / 0$ & 42 & 42 & 84 & $1: 1$ & B4 & 0.000 & 36 & 48 & $1: 1$ & $1 \cdot 714$ \\
\hline G086 & blw/5M & 17 & 11 & 28 & $19: 13$ & (B4) & 0.391 & 15 & 13 & $1: 1$ & $0 \cdot 143$ \\
\hline G099 & $b l w / 2$ & 35 & 55 & 90 & $1: 1$ & B4 & $4 \cdot 440$ & 13 & 77 & $1: 1$ & $45 \cdot 511$ \\
\hline G110 & $b l w / 5 M$ & 23 & 20 & 43 & $1: 1$ & B4 & 0.209 & ns & - & - & - \\
\hline G111 & $b l w / 5 M$ & 47 & 48 & 95 & $1: 1$ & B4 & 0.011 & ns & - & - & - \\
\hline G120 & blw/5M & $39 \dagger$ & 49 & 88 & $1: 1$ & B4 & $1 \cdot 136$ & $39 \dagger$ & 49 & $1: 1$ & $1 \cdot 136$ \\
\hline G093 & $b l w / 5 M$ & 10 & 3 & 13 & $3: 1$ & B2 & 0.026 & 10 & 3 & $3: 1$ & 0.026 \\
\hline G095 & $b l w / 5 M$ & 11 & 4 & 15 & $3: 1$ & B2 & 0.022 & 4 & 11 & $1: 1$ & $3 \cdot 267$ \\
\hline G108 & $b l w / 5 M$ & 55 & 18 & 73 & $3: 1$ & B2 & 0.005 & ns & - & - & - \\
\hline G118 & $b r w / 5 M$ & 45 & 23 & 68 & $3: 1$ & B2 & $2 \cdot 824$ & 43 & 25 & $2: 1$ & $0 \cdot 360$ \\
\hline G089 & $b r w / 4 M$ & 46 & 25 & 71 & $5: 3$ & B6 & $0 \cdot 159$ & 41 & 30 & $1: 1$ & $1 \cdot 704$ \\
\hline G094 & $b l w / 5 M$ & 22 & 12 & 34 & $5: 3$ & B6 & 0.071 & 11 & 23 & $1: 1$ & $4 \cdot 235$ \\
\hline G104 & blw/5M & 23 & 13 & 36 & $5: 3$ & B6 & 0.030 & 21 & 15 & $1: 1$ & 1.000 \\
\hline G106 & $b l w / 5 M$ & 49 & 29 & 78 & $5: 3$ & B6 & 0.003 & 46 & 32 & $2: 1$ & 2.077 \\
\hline G091 & $b l w / 5 M$ & 67 & 13 & 80 & $27: 5$ & (B7) & 0.024 & 50 & 30 & $2: 1$ & 0.625 \\
\hline G101 & blw/5M & 62 & 15 & 77 & $13: 3$ & B7 & 0.027 & 60 & 17 & $3: 1$ & 1.052 \\
\hline
\end{tabular}

Includes one $\left(^{*}\right)$ and five $(\dagger)$ melanic LW classed as HW. ns $=$ not scored 